\title{
EFFECT OF CONSERVATION MANAGEMENT PRACTICES ON SAND GRASSLAND VEGETATION IN BUDAPEST, HUNGARY
}

\author{
BAJOR, Z. $^{1 *}$ - ZIMMERMANN, Z. ${ }^{2}-$ SZABÓ, G. ${ }^{2}-$ FEHÉR, ZS. ${ }^{1}-$ JÁRDI, I. ${ }^{1}-$ LAMPERT, R. ${ }^{3}-$

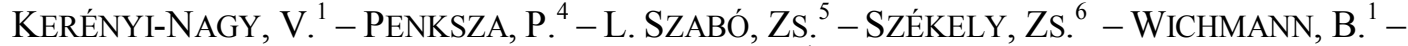 \\ PENKSZA, K. ${ }^{1}$ \\ ${ }^{I}$ Szent István University, Institute of Botany and Plant Ecophysiology, H-2100 Gödöllö, Páter \\ K. Str. 1., Hungary$$
\text { (phone: + } 3628522000,+3628410804)
$$ \\ ${ }^{2}$ Institute of Ecology and Botany, MTA Centre for Ecological Research, H-2163 Vácrátót, \\ Alkotmány Str. 2-4., Hungary \\ (phone: +3630360 122, fax: + 3628360 110) \\ ${ }^{3}$ Corvinus University of Budapest, Faculty of Landscape Architecture, Department of \\ Landscape Planning and Regional Development \\ H-1118 Budapest, Villányi út 29-43. \\ (phone: +36-1-482 6308, fax: +36-1-482 6333) \\ ${ }^{4}$ Corvinus University of Budapest, Faculty of Food Science, Department of Food Preservation \\ H-1118 Budapest, Villányi út 29-43. \\ (phone: +36-1-482-6212, fax: +36-1-482 6324) \\ ${ }^{5}$ University of Debrecen, Institute of Crop Science, H-4032 Debrecen, Böszörményi Str. 138. \\ (phone: +36 52-508 444, fax: +36-52-413 385) \\ ${ }^{6}$ Institute of Environmental Science, Szent István University, \\ H-2100 Gödöllö, Páter K. u. 1., Hungary \\ (phone: +36-28-522-000, fax: +36-28-410-804)) \\ *Corresponding author \\ e-mail: bajor.zoltan@mme.hu \\ (Received 12 $2^{\text {th }}$ Jul 2014; accepted $25^{\text {th }}$ Apr 2016)
}

\begin{abstract}
Despite the large-scale human presence in cities, valuable natural habitat fragments survived, displaying outstanding biodiversity. In and around Budapest (Hungary), species-rich sandy grassland vegetation has shrunk drastically and has remained only in small patches and fragments. The presence of invasive plants is a serious problem in all protected sites of Budapest because they endanger the flora and fauna of the isolated habitats. At the Újpest Homoktövis Nature Conservation Area, conservation interventions have been taking place since 2006 to preserve the grassland fragments in the long term. We followed the effects of this management by surveying coenological relevés in ten permanent quadrats of 1 $\times 1 \mathrm{~m}$ each in seven sample sites in 2012 and 2013. We evaluated the coenological records according to the relative ecological indicators (water and nitrogen) of the species. Detrended correspondence analysis (DCA) was also used for data analysis. Changes of the vegetation could be clearly observed during a 7year-long period, because the species of the sandy grassland have become dominant and this was favourable regarding the aims of the nature conservation. In the stands where management had been carried out for 7 years, a natural or nearly natural vegetation developed, and invasive species and weeds disappeared.

Keywords: habitat reconstruction, grassland restoration, nature conservation management, sandy grasslands, invasive plant species, habitat in urban environment, Újpest Homoktövis Természetvédelmi Terület
\end{abstract}




\section{Introduction}

Geographically, the area of Budapest lies in a varied area, where different types of habitat can be found within relatively small distances (Pécsi, 1958, 1959). Due to its diversity, the area of the city has been populated for a long time, however, from administrative aspects, Budapest - as the result of the unification of three individual towns - can look back only to 140 years of history. From the XVII. century a growing number of studies appeared that aimed to discover wildlife (Bajor, 2009), and reached the same conclusion: thanks to its geographical features, the original wildlife of the present capital is unique and rich in species. In order to implement adequate nature conservation management today, it is essential to know the structure and changes of the original flora and fauna, based on former surveys.

In the first half of the XVIII. century only the hydrography of the Danube was studied (Marsigli, 1726). Afterwards, a prosperity of floristic studies could be observed; its first pioneers were the employees of the Botanical Gardens (Winterl, 1788). Apart from the present area of Budapest, the role of the surrounding areas became more remarkable and a plant identification handbook (Sadler, 1818, 1826, 1840) was prepared based on the studies in the area. Professional publications originally written in Latin were also published or updated in Hungarian (Gönczy, 1864). Parallel to the increasing dominance of Linnaeus' approach, the collective examination of species and their environment started to separate in surveys in Budapest (Bajor, 2011). Later a publication emphasized the unique character of the flora of the landscape (Borbás, 1872). However, an increasing number of scientists have drawn attention to the contraction and degradation of the natural wildlife in the area of Budapest since the early 1990s (Pénzes, 1942; Pénzes and Csízy, 1956; Pécsi, 1958, 1959). By the end of the 20th century, studies of the remaining local fragments has become characteristic because large, coherent areas practically had been abolished by then (Rakonczay, 1992; Simon, 1994; Tardy, 1996; Seregélyes et al., 1996-1997; Pintér 2008).

Research on invasive plants also started in the beginning of 2000s. The presence of invasive plants is a serious problem in all protected sites of Budapest because they endanger the flora and fauna of the isolated habitats (Bajor, 2011). The most dangerous of these species are Robinia pseudoacacia, Ailantus altissima, Acer negundo, Eleagnus angustifolia, Solidago canadensis and Asclepias syriaca, and their spread is becoming more intense not only in Budapest but also nationwide. Based on surveys, the extent of the area infested by invasive plants exceeds 1 million hectares in Hungary. Due to their uncontrolled diffusion, the costs of their suppression are increasing from year to year (Mihály and Botta-Dukát, 2004; Udvardy, 1998, 2008a, 2008b). Therefore, the importance of the habitat reconstruction activities is increasing, which usually aim at preserving the isolated but still remaining habitat fragments and, also at reducing the isolation and increasing the extent of grassland patches, if possible (Critchley et al., 2003). These aims can often be reached by habitat restoration, the main objective of which is to restore the original, initial state of the habitat, regarding the present possibilities (Clewell, 2000).

The Újpest Homoktövis Nature Conservation Area ("Természetvédelmi Terület", hereafter Ujpest Homoktövis TT) represents one of the last fragments of the former rich sandy grassland vegetation that has shrunk drastically in the last centuries and was thus selected as our study site. Although Raymund Rapaics carried out the first coenological relevés in the area, the actual surveys became regular only after the first half of the 1970s, as the result of the activity of Tibor Simon and his colleagues (Seregélyes et al., 
1996-1997). They recognized the outstanding importance of this area, which resulted in the area being declared a nature conservation area in 1974. However, the first studies revealed that the most valuable parts were left out from the reserve and the protection was extended in 1999. Although this area was a closed military area, the degradation and fragmentation of the sandy grassland vegetation had already become significant and was further enhanced by the construction of the Budapest Waterworks by 1999 (Seregélyes et al., 1996-1997). Since then the advance of non-native, mainly woody, species has been observed. These detrimental processes warranted conservation actions, which targeted the restoration of the site. The general aim of this study was to follow the effects of habitat restoration. More specifically, we asked the following questions:

1. How do the restoration activities affect the species number, diversity and species composition of the vegetation?

2. How did the amount of dominant species change during the examined interval (7 years)?

3. How did the vegetation change from 2012 to 2013 in the same quadrats?

\section{Material and methods}

\section{Study site}

The study area lies on the Pest plain near the left bank of the Danube (Dövényi, 2010). The study area is found within the boundaries of Budapest in the northern part of the Ujpest district, and represents a unique natural value of the capital (Verseczki et al., 2007).

The bedrock is decisively river sand brought by the Danube, and also contains calcium, magnesium and bicarbonate. The grain size of the sand, which played an important role in the emergence of the area, varies between 0.02 and $2 \mathrm{~mm}$ (Stefanovits et al., 1999; Poller, 2012). A small amount $(<1 \%)$ of organic material is also present in the sandy habitats, however, its volume increased strongly in the edge zone of the sandy grass remains due to the invasive woody plants.

The Újpest Homoktövis TT was first proposed for protection in the 1950s, but was finally designated in 1974 (Pécsi, 1959; Seregélyes et al., 1996-1997). The protection originally covered 5.7 ha, and it was extended to 24 ha in 1999 and to 40 ha in 2013. Currently the occurrence of 22 protected and specially protected plants is known here. The area was named after the sea buckthorn (Hippophae rhamnoides), because it is the only registered wild occurrence of this species in Hungary, although some researchers debate this (Papp, 1982; Babulka and Turcsányi, 1987; Farkas, 1998; Láng, 2002; Szalay, 2010). From invasive species, Robinia pseudoacacia, Pinus nigra, Eleagnus angustifolia and Acer negundo cover the largest area in the nature reserve (Seregélyes et al., 1996-1997).

\section{Conservation management}

In order to preserve the grassland fragments in the long term, conservation interventions have been taking place in the habitat of Hippophae rhamnoides since 2006. We have performed this activity with official permission and with the help of volunteers from the Budapest Group of the Hungarian Ornithological and Nature Conservation Society and students from several educational institutions (1200 volunteers so far).

We carried out habitat management strictly after the growing season on 28 occasions between 2006 and 2013. 
Management included the mechanical beating down of sprouts of invasive species, and chemical parching of their stems. Management actions were planned systematically, and we managed to clear invasive plants in an area of c. 5 ha in the last seven years. As a result, c. $40 \%$ of the treated area regenerated and became sand grassland again. In the first period this value was only about half of the current rate, i.e. only $20 \%$ of the habitat was free of woody invasive plants.

\section{Data collection}

Reflecting the sites of the yearly treatments between 2006 and 2013, we divided the area into seven sample areas. After the first treatment, maintenance activities took place in every sample area for the following four years, and in addition, eradication and mowing was performed, if necessary.

Accordingly, we studied different phases of sandy grasslands in the following seven sample areas: I: no treatment, the area has been a natural grassland for more than 20 years, II: treated (invasive woody species cleared) in 2006, III: treated in 2007, IV: treated in 2008, V: treated in 2009, VI: treated in 2010 (it emerged after the shrub eradication, that this area was filled with debris and on this surface shrubs and trees began to grow), VII: treated in 2011.

We designated coenological relevés in ten permanent quadrats of $1 \times 1 \mathrm{~m}$ in each sample area, and recorded cover values of all vascular plant species in percentages. We defined the bottom left corners of the quadrats by GPS coordinates. Sampling was carried out in 2012 and 2013. For plant species nomenclature, we used Király (2009), and for plant communities, we followed Borhidi et al. (2012).

\section{Data analysis}

We evaluated the coenological records according to the relative ecological indicators (here we used water and nitrogen demand) of the vascular plant species (Borhidi, 1995) based on the database „Flóra" (Horváth et al., 1995). We calculated the Shannon diversity index for all 70 quadrats, covering both sampling dates. We calculated with the species whose estimated cover exceeded $8 \%$ as per the averaged quadrats as dominant.

In order to present the similarities and differences between the areas, we used a cluster analysis based on the Bray-Curtis matrix of dissimilarity, and an ordination (Pavlů et al., 2011). Hierarchical clustering with complete linkage methods were computed for dendrograms in which each element classify of its own. Each clusters combined sequentially into larger clusters until these elements are in the same clusters. Always the shortest distances are combined. Detrended correspondence analysis (DCA) was used for data analysis.

We combined the data of each species recorded in the quadrats, and if one species was found simultaneously in several various areas during one year, we considered the highest cover value for DCA analysis. We used this method of simplification instead of the averaging method, because using the averaging method, the determinant dissimilarities and the higher average cover values of the portions of areas might have disappeared. Further, this method was the best one to conform with our sampling method. After elimination of outliers two main axes represented with this multivariate technique: observed species and divergent areas taken into investigation. DCA is superior in nonmetric multidimensional scaling hence its an improved reciprocal averaging technique. DCA limitations are related with extreme outliers so the best to remove them before analysis. 
We conducted all analyses using the program R 3.02. (R Development Core Team 2015).

\section{Results}

\section{Vegetation of the areas}

The number of species decreased significantly from 2012 to 2013 in areas 1-5 (MannWhitney test, $\mathrm{p}<0.05)$. The smallest decrease was in area I. There was no clear tendency in species numbers among areas when years were considered separately (Table 1).

Table 1. Average species number ( $\pm S D$ ) in the study areas

\begin{tabular}{|c|c|c|c|c|c|c|c|}
\hline & I & II & III & IV & V & VI & VII \\
\hline 2012 & $9 \pm 3$ & $15 \pm 2$ & $11 \pm 2$ & $13 \pm 3$ & $16 \pm 3$ & $13 \pm 4$ & $12 \pm 3$ \\
\hline 2013 & $6 \pm 2$ & $8 \pm 2$ & $8 \pm 2$ & $9 \pm 3$ & $10 \pm 3$ & $12 \pm 4$ & $14 \pm 4$ \\
\hline
\end{tabular}

However, species compositions changed in various directions between years and among areas. In areas I and II, species composition was nearly identical in every relevé, and the common dominant species were Festuca vaginata, Stipa borysthenica and Peucedanum arenarium. While Fumana procumbens was dominating in site I, its cover values decreased in site II. In site II, cover values of Festuca pseudovaginata increased similarly to Festuca vaginata, which is a characteristic and dominant species for sandy grasslands.

The dominance relationships of the two Festuca species changed among areas because Festuca pseudovaginata had relatively high cover values in site II and V, while Festuca vaginata was dominant in site I and III. Stipa borysthenica occurred in sites I$\mathrm{V}$ and VII and missing in site VI. Stipa capillata was present in sites I-IV with relatively low cover values and it did not occur in sites V-VII (Table 2.).

Table 2. Mean cover values of the dominant species in the study areas (FES_PSE: Festuca pseudovina, FES_VAG: Festuca vaginata, STI_BOR: Stipa borysthenica, STI_CAP: Stipa capillata)

\begin{tabular}{|l|c|c|c|c|}
\hline & FES_PSE & FES_VAG & STI_BOR & STI_CAP \\
\hline $\mathrm{I} / 2012$ & 0,00 & 12,10 & 3,00 & 0,00 \\
\hline $\mathrm{I} / 2013$ & 0,00 & 8,70 & 4,70 & 0,40 \\
\hline $\mathrm{II} / 2012$ & 4,20 & 5,10 & 7,80 & 0,50 \\
\hline $\mathrm{II} / 2013$ & 5,00 & 0,80 & 10,90 & 0,00 \\
\hline $\mathrm{III} / 2012$ & 1,00 & 11,50 & 2,50 & 0,40 \\
\hline $\mathrm{III} / 2013$ & 0,44 & 16,11 & 2,22 & 3,33 \\
\hline $\mathrm{IV} / 2012$ & 0,00 & 3,90 & 1,80 & 1,30 \\
\hline $\mathrm{IV} / 2013$ & 0,00 & 1,00 & 2,00 & 0,30 \\
\hline $\mathrm{V} / 2012$ & 4,10 & 0,00 & 0,60 & 0,00 \\
\hline $\mathrm{V} / 2013$ & 8,10 & 2,50 & 2,60 & 0,00 \\
\hline $\mathrm{VI} / 2012$ & 0,00 & 0,00 & 0,00 & 0,00 \\
\hline $\mathrm{VI} / 2013$ & 0,00 & 0,00 & 0,00 & 0,00 \\
\hline $\mathrm{VII} / 2012$ & 0,20 & 0,00 & 0,00 & 0,00 \\
\hline $\mathrm{VII} / 2013$ & 2,48 & 0,50 & 0,64 & 0,00 \\
\hline
\end{tabular}


The distribution of the woody species is also important since it indicates the success of the conservation treatment. Six invasive woody species occurred mostly in sites V VII: Ailanthus altissima, Acer negundo, Populus canadensis, Robinia pseudoacacia, Fraxinus pennsylvanica and Celtis occidentalis (Fig. 1.). The native shrubs and trees were almost missing from areas I-IV, whereas their amount was higher in sites V-VII.

Invasive trees and shrubs (surveys by date)

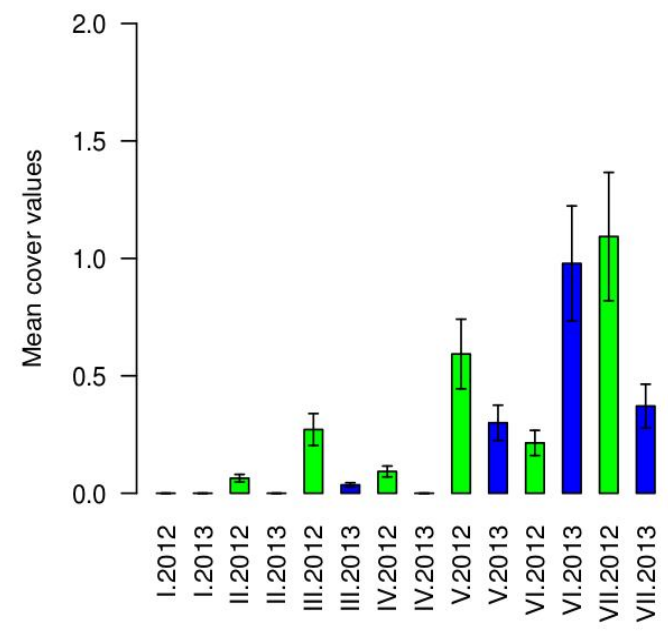

Native trees and shrubs (surveys by date)

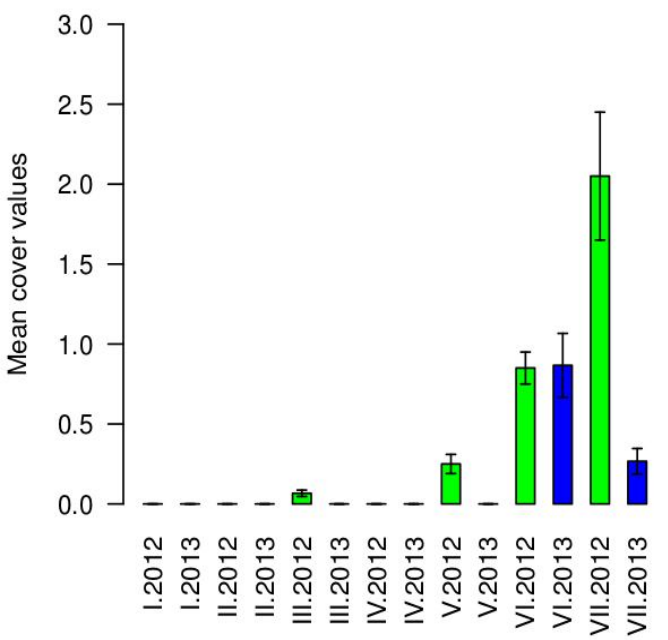

Figure 1. Mean cover of invasive and native woody species in the study areas

The cover of weed species was high in areas VI and VII, and in areas which had been treated for a longer period of time, the proportion of weeds was reduced (Fig. 2). Significant difference were determined among 14 distinct examined groups with Kruskall-Wallis test (chi-squared $=102.7425, \mathrm{df}=13, \mathrm{p}$-value $=4.871 \mathrm{e}-16$ ). Coverage of weeds significantly decreased in area VI $(\mathrm{p}=0.0480)$ and VII. $(\mathrm{p}=0.0177)$ between years 2012 and 2013 (Fig. 2.).

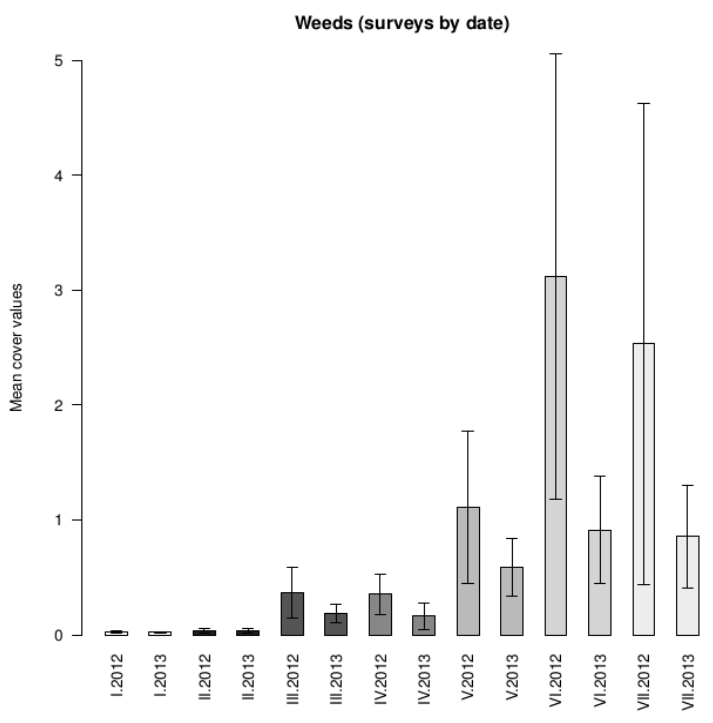

Figure 2. Occurrence of weed species in the study areas 
The relevés of 2013 showed a less diverse state, except two areas (I and VII). In areas II-V, nearly the same diversity values were observed in 2012. In these areas, diversity was higher than in site I (natural grassland) because the presence of weed species caused an increase in diversity. The lowest diversity was found in area I in 2012 and in area VI in 2013. In area I, diversity was relatively low in both years and showed no change, in contrast to the other, treated areas (Fig. 3.). Kruskall-Wallis test showed significant difference among distinct examined groups (chi-squared $=48.1906, \mathrm{df}=13$, $\mathrm{p}$-value $=6.073 \mathrm{e}-06)$. Shannon diversity values showed significant $(\mathrm{p}<0.05)$ differences among VI (2013) and II (2012 and 2013), VII (2013). There was no significant differences among groups in every other comparisons.

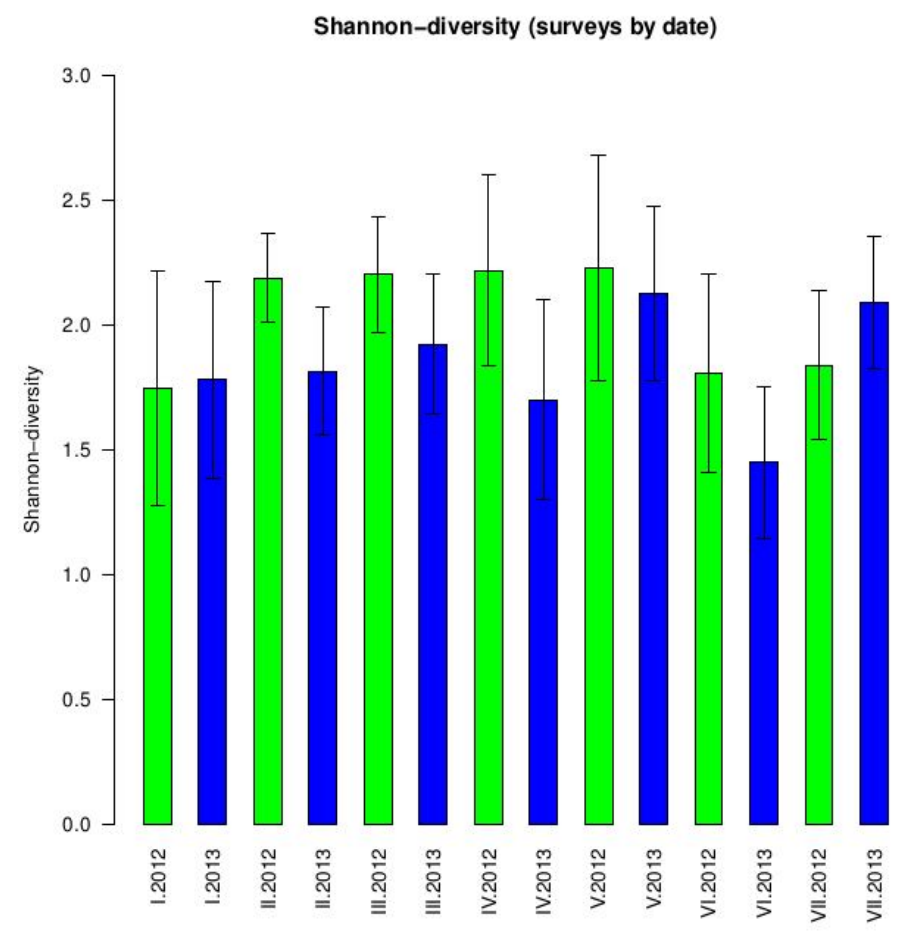

Figure 3. Diversity values in the seven areas in 2012 and 2013

Based on the classification of the coenological relevés (Fig. 4.), species of areas VI and VII showed the highest deviation from those of the other areas because of the higher amount of weed species. The quadrats of area VI formed a relatively distinct group. Records from area I and II were also separated from the other groups (these are the relevés from the natural grassland and the area treated for the longest time). The fragmentation is based on the amount of the dominant species (Festuca vaginata, F. pseudovaginata, Poa bulbosa, Carex liparicarpos, Fumana procumbens).

The DCA analyses showed that Clematis vitalba, Melandrium album and Oenothera biennis occuring in areas VI and VII were clearly separated from the rest of the species. Characteristic sandy grassland species (Festuca pseudovaginata, Festuca vaginata, Potentilla arenaria, Peucedanum arenarium and Fumana procumbens) formed another group. These species occurred both in the natural grasslands or in previously treated areas (areas I-V.). The invasive species (Robinia pseudoacacia, Ballota nigra, 
Ambrosia artemisifolia, Conyza canadensis) also formed a sharply separated group. These species were also found in the recently treated areas VI and VII. Area VII differed greatly between the two years, in 2012 it was very different from the other relevés, whereas in 2013 it was very similar to them. The reason can be that after shrub eradication the species composition of weeds changed rapidly, weed species occurred in the first year were disappeared one year later.

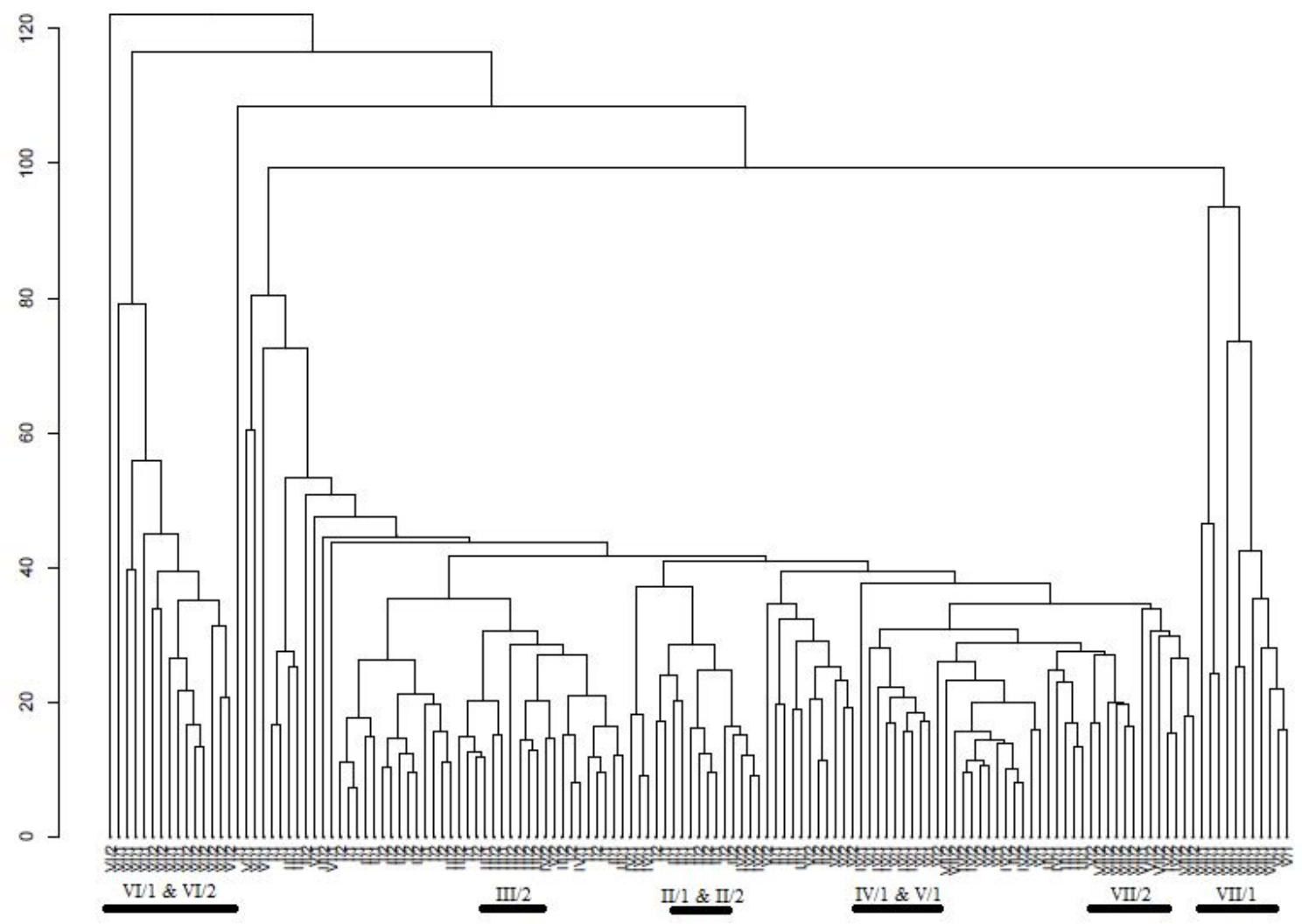

Figure 4. Dendrogram of the coenological relevés of the study sites (1:2013, 2: 2012)

Mainly areas I and VII were separated. Invasive species were also found in areas V, VI and VII; however the analysis showed that they disappeared in areas I-IV. The aggregation of areas I, II, III and IV demonstrates the adequate environmental conditions of the sand species. Areas VI and VII were mostly covered by weeds and invasive species, because regeneration of the sandy grassland had started there only a short time ago.

Fig. 5. shows the shift in the vegetation. In area I, the records of 2012 and 2013 overlapped substantially. In contrast, records from the two years separated greatly from one another in area VI and particularly in area VII, demonstrating that the vegetation was going through a transformation in these recently managed areas. Species composition of area I can be regarded stable from a coenological point of view. In contrast, area VII is in the beginning of the regeneration process and in course of this, rapid changes in the weed species composition can cause coenological variation between years. 

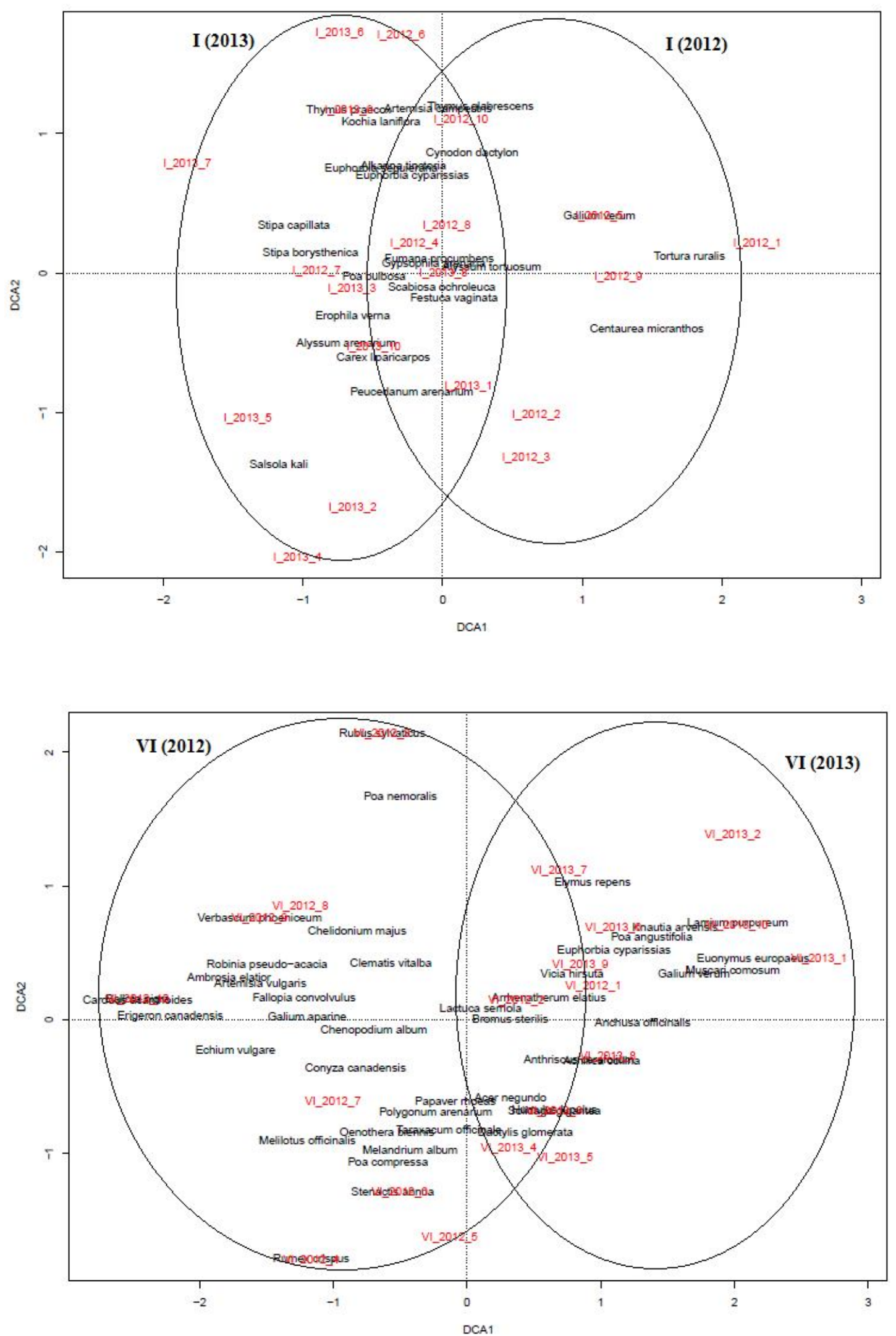

APPLIED ECOLOGY AND ENVIRONMENTAL RESEARCH 14(3): 233-247.

http://www.aloki.hu • ISSN 15891623 (Print) • ISSN 17850037 (Online)

DOI: http://dx.doi.org/10.15666/aeer/1403_233247

(c) 2016, ALÖKI Kft., Budapest, Hungary 


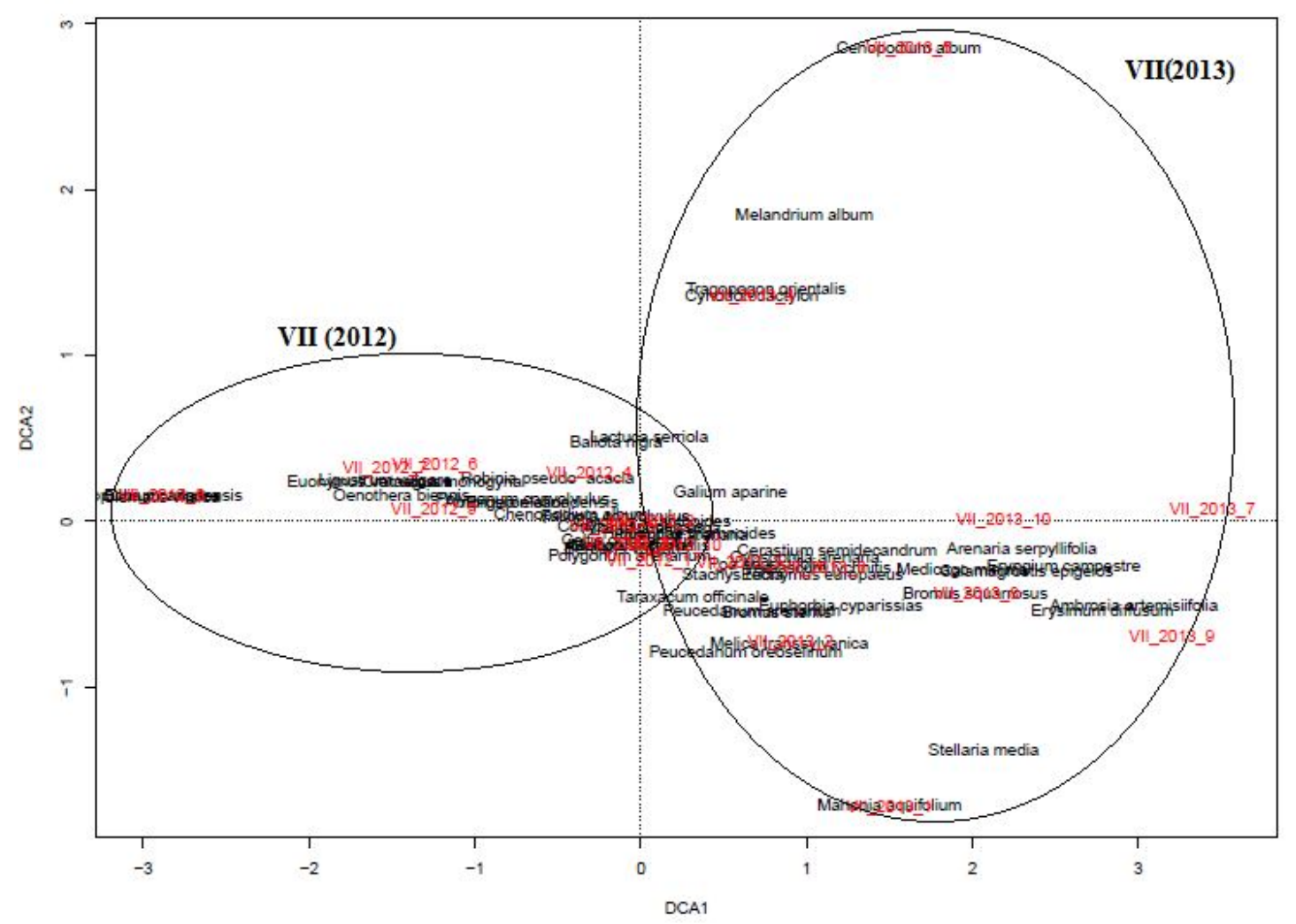

Figure 5. DCA (Detrended Correspondence Analysis) representation of the frequent plant species on the relevés of 2012 and 2013 in sites I, VI and VII

\section{Analysis of the vegetation of sites based on relative ecological indicator values}

Areas I and II had the highest cover of species requiring nutrient-poor soils (categories 1 and 2) on the basis of their relative nitrogen demand, followed by areas III and IV (Fig. 6). Area V was a submesotrophic and slightly nutrient-rich habitat (categories 3 and 4). In areas VI and VII, the cover of plants indicating medium (category 5) and high nitrogen volume (categories 7 and 8) was also high. From 2012 to 2013, the proportion of plants indicating different levels of nitrogen volume shifted. Although the cover of plants in categories 1 and 2 was similarly high in 2012 and 2013 in area I, it increased from 2012 to 2013 in areas II to V, and the difference was larger in more recently managed areas (Fig. 6). In area IV, a spectacular shift appeared toward species demanding less nitrogen; the cover of species in categories 1 and 2 increased, while that of species in category 3 decreased. In area $\mathrm{V}$, this process just started (Fig. 6).

On the basis of the relative water demand of the species, drought indicator plants (categories 1 and 2) had the highest proportion in area I in 2012 (Fig. 7.). In area II, species typical in habitats of long drought periods (category 2 ) increased considerably from 2012 to 2013, resulting in a similar cover of category 1 and 2 plants in areas I and II in 2013. In site I, the cover of rocky, semi-desert species was highest in 2013. The proportion of drought-tolerant species decreased in areas with more recent management and the proportion of species of more humid areas, including forest species, increased as advancing from area III through VII. The proportion of species with different levels of relative water demand also shifted from 2012 to 2013. Again, the increase in the proportion of drought indicator species (categories 1 and 2) was greater in areas with 
more recent management (Fig. 7), i.e. the earlier the shrub eradication, the higher the proportion of drought indicator plants. On the basis of these data, area VI represents an outstanding peak, similarly to the case with relative nitrogen demand.

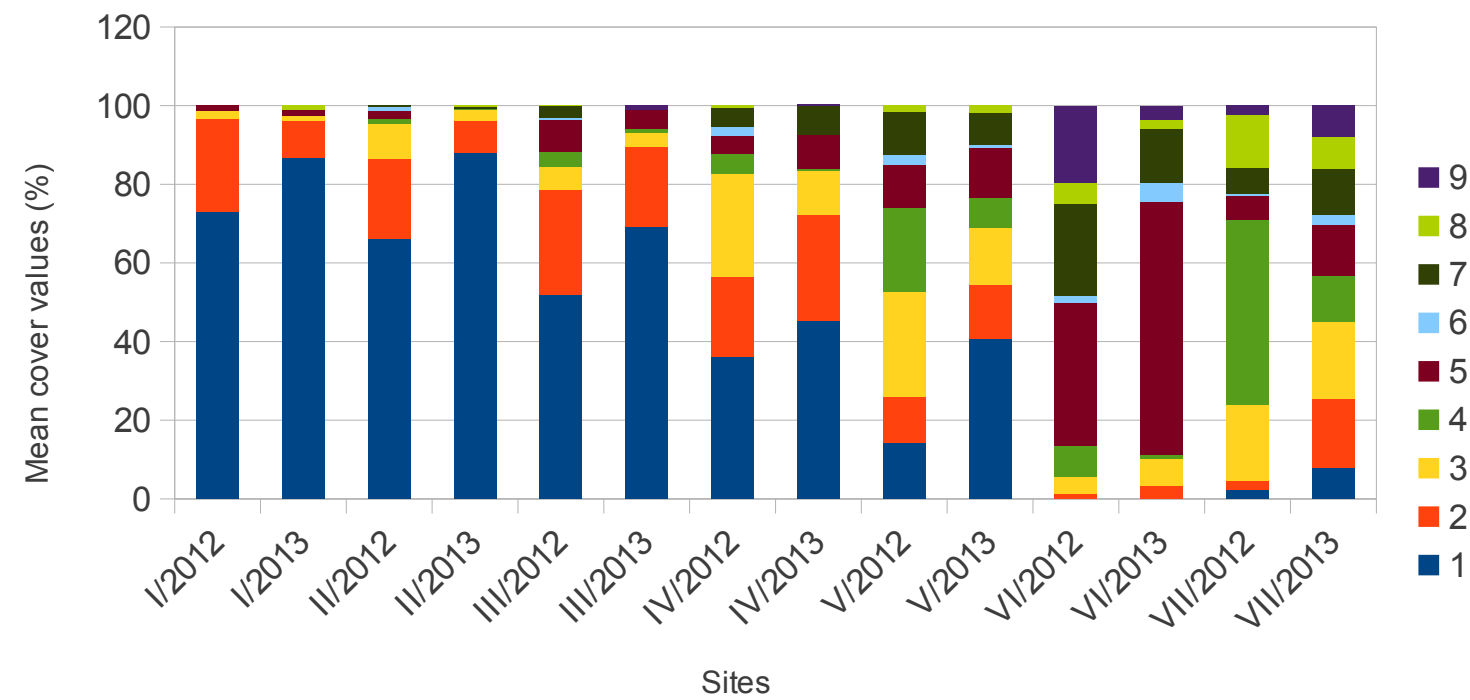

Figure 6. Average cover values of species according to their relative nitrogen demand.

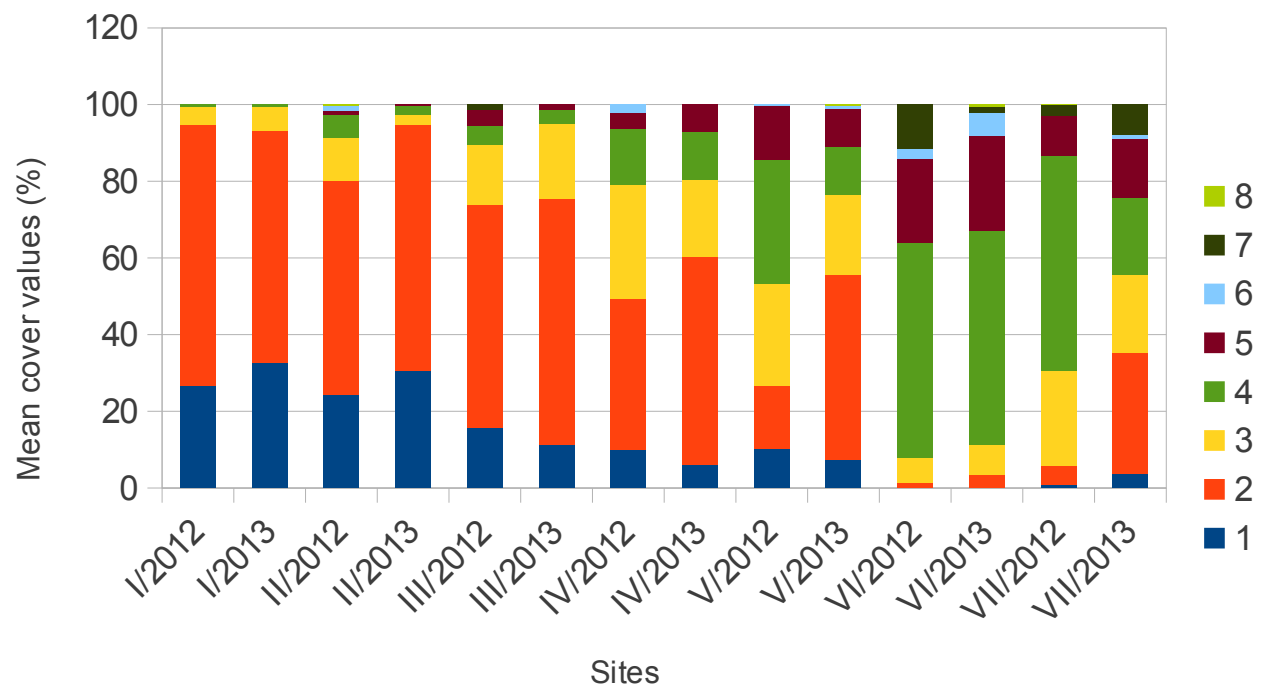

Figure 7. Average cover values of species according to the relative water demand

\section{Discussion}

Nowadays the issue of habitat reconstruction is becoming more significant, and an increasing number of studies deal with the active restoration of valuable habitats (Török et al. 2009; Vida et al., 2008; Penksza et al., 2011). However, the restoration of natural and semi-natural habitats in urban environments is almost unknown in Hungary (Kézdy and Tóth, 2013). In order to accelerate the restoration process, over-sowing 
with seed-mixture is used in many cases (Bakker, 1989; Jongepierová et al., 2007; Török et al., 2009). In this study, overseeding did not seem appropriate because fragments of the original plant communities existed as a propagulum source (Pintér, 2008).

Changes in the vegetation could be clearly observed during a 7-year-long period. The most important change was that species of sandy grasslands have become dominant, which can generally be regarded as positive for nature conservation (Borhidi et al., 2012). Regarding our first question, our study also shows that as a result of the gradual removal of invasive woody plants, favourable conditions can be established for species of sandy grasslands in the long term. Based also on the findings of other studies, the short-term post-treatment (mowing) caused significant changes and a further increase in species richness can be expected (Ilmarinen and Mikola, 2009; Török et al., 2007; Vida et al., 2008).

Our results showed that continuous sandy grassland regenerated in study areas II and III, where conservation management has taken place for 7 years. Our coenological data showed that weeds and invasive species have gradually disappeared from the natural reserve area, and that species composition has also become more similar to the sandy vegetation. In contrast to other data indicating that the spontaneous restoration of grasslands can be very slow (Török et al., 2008), the process is taking place at a rapid pace in the study area.

Regarding our second question, we found that in stands where conservation management had been carried out for seven years, a natural or nearly natural vegetation developed. In these quadrats, invasive species and weeds have practically disappeared. Our investigations revealed that as a consequence of the treatments the stands of Festuca vaginata and Festuca pseudovaginata have been continuously increasing. Instead of Festuca vaginata, Festuca pseudovaginata is becoming dominant in disturbed areas (Penksza, 2003), which has been confirmed by our results. On the basis of the ecological indicators, area VI (where management had been carried out earlier) is displaying a more unfavourable view than site VII. The most important change was detected in case of indicator values of nitrogen demand. After shrub eradication topsoil contains more humus and nutrients yet which originated from the leaves of the former woody vegetation. However, in course of leaching of soil amount of nutrients probably decreasing rapidly year by year, which can cause that less and less species with high nitrogen demand occur.

Acknowledgements. Reserch Center of Excellence-9878-3/2016/FEKUT.

\section{REFERENCES}

[1] Babulka, P., Turcsányi, G. (1987): Természetvédelmi terület vagy szemétlerakóhely? Veszélyben az újpesti homoktövis [Nature conservation area or dump? Sea buckthorn in danger in Újpest] - Búvár 42(3): 38-39 (in Hungarian)

[2] Bajor, Z. (2009): Budapest természeti kalauza [Nature guide of Budapest] - Kossuth Kiadó, Budapest (in Hungarian)

[3] Bajor, Z. (2011): Özönnövények és egyéb tájidegen növényfajok előfordulása Budapest helyi védettségü természeti értékein [Occurence of invasive plant species in the local nature conservation areas in Budapest] - Fővárosi Önkormányzatnak készített tanulmánykötet, Budapest (in Hungarian) 
[4] Bakker, J. P. (1989): Nature management by grazing and cutting. On the ecological significance of grazing and cutting regimes applied to restore former species rich grassland communities in the Netherlands - Kluwer Academic Publishers, Dordrecht

[5] Borbás, V. (1872): Pest-megye flórája Sadler óta és újabb adatok [New data to the flora of Pest county] - Math. Term. Közlem. 9:15-54. (in Hungarian)

[6] Borhidi, A. (1995): Social behaviour types, the naturalness and relative ecological indicator values of the higher plants in the Hungarian flora. - Acta Botanica Hungarica 39(1-2): 97-181.

[7] Borhidi, A., Kevey, B., Lendvai, G. (2012): Plant communities of Hungary - Akadémiai Kiadó, Budapest

[8] Clevell, A. F. (2000): Restoring for natural authenticity - Ecological Restoration 18: 216217.

[9] Critchley, C. N. R., Burke, M. J. W., Stevens, D. P. (2003): Conservation of lowland semi- natural grasslands in the UK: a review of botanical monitoring results from agri-environment schemes - Biological Conservation 115: 263-278.

[10] Dövényi, Z. [ed.] (2010): Magyarország kistájainak katasztere [Inventory of microregions of Hungary] - Magyar Tudományos Akadémia, Földrajztudományi Kutatóintézet, Budapest (in Hungarian)

[11] Farkas, S. (1998): Magyarország védett növényei [Protected plants of Hungary] Mezőgazda kiadó, Budapest (in Hungarian)

[12] Gönczy, P. (1879): Pest megye és tájéka viránya [Flora of Pest county and surroundings] Magyar Királyi Egyetemi Ny., Budapest (in Hungarian)

[13] Horváth, F., Dobolyi, Z. K., Morschhauser, T., Lőkös, L., Karas, L., Szerdahelyi, T. (1995): Flóra adatbázis 1.2. Taxonlista és attribútum állomány. [Data base of flora 1.2. Taxonomy list and attributes.] - MTA ÖBKI, Vácrátót (in Hungarian)

[14] Ilmarinen, K., Mikola, J. (2009): Soil feedback does not explain mowing effects on vegetation structure in a semi-natural grassland - Acta Oecologica 35(6): 838-848.

[15] Jongepierova, I., Mitchley, J., Tzanopoulos, J. (2007): A field experiment to recreate species rich hay meadows using regional seed mixtures - Biological Conservation 3: 297305.

[16] Kézdy, P., Tóth, Z. [eds.] (2013): Természetvédelem és kutatás a budai Sas-hegyen. Tanulmánygyüjtemény [Nature conservation and research in Sas-hegy. Case studies] Duna-Ipoly Nemzeti Park Igazgatóság, Budapest (in Hungarian)

[17] Király, G. [ed.] (2009): Új magyar füvészkönyv. Magyarország hajtásos növényei. Határozókulcsok [New Hungarian herbal. The vascular plants of Hungary. Identification key] - ANP Igazgatóság, Jósvafö (in Hungarian)

[18] Láng, I. [EIC] (2002): Környezet- és Természetvédelmi Lexikon I. [Encyclopedia of nature conservation and environment protection] - Akadémia Kiadó, Budapest (in Hungarian)

[19] Marsigli, L.F. (1726): Danubius pannonico-mysicus. Reprint by Andras, D.A. 2004 . Vízügyi Múzeum, Budapest

[20] Mihály, B., Botta-Dukát, Z. [eds] (2004): Biológiai inváziók Magyarországon Özönnövények [Biological invasions in Hungary - Invasive plants] - Természetbúvár Alapítvány Kiadó, Budapest (in Hungarian)

[21] Papp, L. (1982): A homoktövis jelentősége és szaporítása [Importance and propagation of Hippophae rhamnoides] - Az erdő, 7: 309-312. (in Hungarian)

[22] Pavlů, L., Pavlů, V., Gaislera, J., Hejcman, M., Mikulka, J. (2011): Effect of long-term cutting versus abandonment on the vegetation of a mountain hay meadow (PolygonoTrisetion) in Central Europe - Flora 206: 1020-1029.

[23] Penksza, K. (2003): Festuca pseudovaginata, a new species from sandy areas of the Carpathian Basin. - Acta Bot. Hung. 45: 356-372.

[24] Penksza, K., Szentes, Sz., Loksa, G., Dannhauser, C., Házi, J. (2011): A legeltetés hatása a 
gyepekre és természetvédelmi vonatkozásai a Tapolcai- és a Káli-medencében [Nature conservation aspects of grazing in the Tapolca and Káli Basins] Természetvédelmi Közlemények 16: 33-57 (in Hungarian)

[25] Péchy, M. [ed.] (1958): Budapest természeti képe [Environmental characteristics of Budapest] - Akadémiai Kiadó, Budapest (in Hungarian)

[26] Péchy, M. [ed.] (1959): Budapest természetföldrajza [Geography of Budapest] Akadémiai Kiadó, Budapest (in Hungarian)

[27] Pénzes, A. (1942): Budapest élővilága [Wildlife of Budapest] - Királyi Magyar Természettudományi Társulat, Budapest (in Hungarian)

[28] Pénzes, A., Csizy, F. (1956): Budapest élővilága [Wildlife of Budapest] - Társadalom- és Természettudományi Ismeretterjesztő Társulat, Budapest (in Hungarian)

[29] Pintér, B. (2008): Budapest védelemre javasolt területei [Proposed protected areas in Budapest] - Tölgy Természetvédelmi Egyesület tanulmánykötete, Gödöllő (in Hungarian)

[30] Poller, E. F. (2012): Feldarabolódó homokpusztagyepek Dunakeszin és környékén [Fragmented sandy grasslands in Dunakeszi and sorroundings] - BSc. szakdolgozat, SZIE MKK-TTT, Gödöllö (in Hungarian)

[31] Rakonczay, Z. (1992): Sas-hegytől a Kálvária-dombig; Az Észak-Dunántúl természeti értékei [From Sas-hegy to Kálvária-domb; Natural values of the northern part of Dunántúl] - Mezőgazda Kiadó, Budapest (in Hungarian)

[32] R Development Core Team (2015). R: A language and environment for statistical computing. R Foundation for Statistical Computing, Vienna, Austria. ISBN 3-900051-07-0, URL http://www.r-project.org/

[33] Sadler, J. (1818): Verzeichniss der um Pesth und Ofen wildwachsenden phanerogamischen Gewächse mit Angabe ihrer Standorte und Blüthezeit - Pesth

[34] Sadler, J. (1826): Flora comitatus pestiensis - Pestini

[35] Sadler, J. (1840): Flora comitatus Pesthinensis, Ed. 2. - Pesthini

[36] Seregélyes, T., S. Csomós, Á., Szél, Gy., Szollát, Gy. (1996-97): Budapest Főváros természetvédelmi területeinek élővilága 10-7; Az Újpesti Homoktövis Élőhelye [Flora and fauna of the nature conservation areas of Budapest; Habitat of Hippophae rhamnoides in Újpest] - Botanikus Bt., Budapest, 38 p. (in Hungarian)

[37] Simon, T. [ed.] (1994): Természeti kincsek Dél-Budán; A Tétényi-fennsík és a Hárossziget növény- és állatvilága, természetvédelme [Natural values in Dél-Buda; Flora, fauna and nature conservation of the Tétényi-fennsík and Háros-sziget] Cserépfalvi Kiadó - Zöld Jövő, Budapest (in Hungarian)

[38] Stefanovits, P., Filep Gy, Fileky Gy. (1999): Talajtan [Pedology] - Mezőgazdasagi Kiadó, Budapest (in Hungarian)

[39] Szalay, L. (2010): Páratlan gyógyító hatás: A homoktövis [Unique healing effect: The sea buckthorn] - Biokultúra: A Magyar Biokultúra Szövetség szakfolyóirata, 3: 21. (in Hungarian)

[40] Tardy, J. [ed.] (1996): Magyarországi települések védett természeti értékei [Protected natural values of Hungarian settlements] - Mezőgazda Kiadó, Budapest (in Hungarian)

[41] Török, P., Arany, I., Prommer, M., Valkó, O., Balogh, A., Vida, E., Tóthmérész, B., Matus, G. (2007): Újrakezdett kezelés hatása fokozottan védett kékperjés láprét fitomasszájára, faj- és virággazdagságára [Above ground vegetation and phytomass of strictly protected abandoned hay-making Molinion meadows in Zemplén Mountains (Hungary) after restored management] - Természetvédelmi Közlemények 13: 187-197 (in Hungarian)

[42] Török, P., Matus, G., Papp, M., Tóthmérész, B. (2008): Secondary succession in overgrazed Pannonian sandy grasslands - Preslia 80: 73-85

[43] Török, P., Arany, I., Prommer, M., Valkó, O., Balogh, A., Vida, E., Tóthmérész, B., Matus, G. (2009): Vegetation, phytomass and seed bank of strictly protected hay-making Molinion meadows in Zemplén Mountains (Hungary) after restored management Thaiszia - J. Bot., Košice, 19, Suppl. 1: 67-78. 
[44] Udvardy, L. (1998): Classification of adventives dangerous to the Hungarian natural flora. Acta Botanica Hungarica 40: 315-331.

[45] Udvardy, L. (2008a): Boxelder (Acer negundo L.). In: Botta-Dukát Z., Balogh L. (szerk): The most important invasive plants in Hungary. Hungarian Academy of Sciences, Institute of Ecology and Botany, Vácrátót. pp. 121-127.

[46] Udvardy, L. (2008b): Tree of Heaven (Ailanthus altissima (Mill.) Swingle). In: BottaDukát Z., Balogh, L.(szerk): The most important invasive plants in Hungary. Hungarian Academy of Sciences, Institute of Ecology and Botany, Vácrátót. pp. 121127.

[47] Verseczki, N., Lendvai, Cs., Pintér, B. (2007): Az Újpesti homoktövis és élőhelyének védelme [Habitat and protection of Hippophae rhamnoides in Újpest] - Madártávlat, 1: 18- 20. (in Hungarian)

[48] Vida, E., Török, P., Deák, B., Tóthmérész, B. (2008): Gyepek létesítése mezőgazdasági müvelés alól kivont területeken: a gyepesítés módszereinek áttekintése [A review and assessment of grassland restoration techniques in arable lands] - Botanikai Közlemények 95 (1-2): 115-125. (in Hungarian)

[49] Winterl, J. J. (1972): Index Horti Botanici Universitatis Hungaricae, quae Pestini est. 1788. - Facsimile edition, Akadémiai Kiadó, Budapest 